\title{
REVIEW
}

\section{Synovial biopsy in arthritis research: five years of concerted European collaboration}

\author{
Barry Bresnihan, Paul Peter Tak, Paul Emery, Lars Klareskog, Ferdinand Breedveld
}

Department of

Rheumatology, St

Vincents University

Hospital, Dublin 4,

Ireland

B Bresnihan

Division of Clinical Immunology and Rheumatology,

Academic Medical

Centre, Amsterdam,

The Netherlands

P P Tak

Rheumatology

Research Unit,

University of Leeds,

Leeds, United

Kingdom

P Emery

Rheumatology Unit, Department of

Medicine, Karolinska

Hospital, Stockholm,

Sweden

L Klareskog

Department of Rheumatology, Leiden

University Medical

Centre, Leiden,

The Netherlands

$\mathrm{F}$ Breedveld

Correspondence to: Professor Bresnihan

Email: b.bresnihan@svcpc.ie

Accepted for publication 1 May 2000
The term rheumatoid arthritis (RA) was first proposed by Garrod in 1859. ${ }^{1}$ By 1959 , the histopathological features of synovitis, the proliferating pannus, and cartilage degradation in longstanding RA had been well described. ${ }^{2}$ Early histopathological studies were based on tissue samples obtained at surgery or at postmortem examinations. Occasionally, biopsy samples were obtained for analysis from patients with arthritis undergoing open arthrotomy.

\section{Needle biopsy of synovium}

The initial interest in developing synovial biopsy techniques was to aid the differential diagnosis of joint diseases. In 1932 Forestier described a technique for obtaining synovial tissue with a dental nerve extractor that was introduced into the joint through a large calibre needle. ${ }^{3} \mathrm{He}$ never published his results. Early experience with needle biopsy of the synovium was described in the $1950 \mathrm{~s} .{ }^{45}$ It was concluded that if strict aseptic techniques were employed, the procedure was safe and practical for use in both hospital wards and outpatient clinics. However, the biopsy needles tended to cause considerable trauma to the penetrated tissues owing to their wide bore and the requirement for an incision. In 1963 Parker and Pearson developed a simplified 14-gauge biopsy needle that did not require a skin incision. ${ }^{6}$ They described their experience of 125 procedures, almost all from the suprapatellar pouch of the knee joint, of which only five failed to yield adequate tissue for analysis. No serious complications were encountered. The potential of needle biopsy as a research tool in arthritis was highlighted in 1970 by Kinsella et al in their study of synovial lining layer cells in RA, ${ }^{7}$ and in 1972 by Schumacher and Kitridou in their clinicopathological study of the early features of synovitis. ${ }^{8}$

\section{Arthroscopic biopsy of the synovium}

Arthroscopy was also initially developed as a diagnostic instrument. It was used primarily by orthopaedic surgeons. ${ }^{9}$ In the 1970 s and 1980 s a number of academic rheumatology groups, notably in London, Stockholm, Paris and Ann Arbor, introduced arthroscopy as a research tool. With the development of small-bore (for example, $2.7 \mathrm{~mm}$ ) arthroscopes, which can be used in a day-care environment under local anaesthesia, regional nerve block, or general anaesthesia, it became possible to select tissue samples from various large and small joints and from most regions within the joint, including the cartilage-pannus junction. ${ }^{10-12}$ In addition, methods for quantifying intra-articular disease were validated. ${ }^{13}$ These developments were of great interest to rheumatologists as they opened new and exciting opportunities in the field of synovial tissue research. Now, training courses in arthroscopy are regularly organised by EULAR and the ACR. A recently completed international survey of arthroscopy in rheumatology identified 24 academic centres in 10 European countries that regularly use arthroscopic techniques (Kane D, personal communication). Twenty three of these centres have started using arthroscopy since 1990. Arthroscopic biopsy is technically more complicated and more expensive than closed needle biopsy, but it provides larger tissue samples that can be selected under direct vision.

\section{Advances in the analysis of synovial biopsy tissue}

Many technological developments in fields that included electron microscopy, cytochemistry, immunohistochemistry, cell culture, and molecular biology have been successfully applied to synovial tissue research. As a result, detailed descriptions of the synovial membrane and pannus architecture have been published. ${ }^{14-17}$ In addition, many of the pathophysiological mechanisms associated with chronic synovial inflammation and progressive matrix degradation have been identified. ${ }^{18-28}$ It is known that the normal synovium at the cartilage-pannus junction contains mainly inactive fibroblasts and macrophages. ${ }^{29}$ In RA and some other forms of arthritis these cell populations increase in number and become highly activated and transformed. They produce many proinflammatory and destructive mediators, which enable them to invade cartilage and bone. ${ }^{30} 31$ In addition, these cells and their products may modulate other cell populations participating in tissue degradation. ${ }^{32-34}$ At the same time the inflamed synovium demonstrates prominent new blood vessel formation, ${ }^{35}$ and the accumulation of antigen-presenting cells, $\mathrm{T}$ and $\mathrm{B}$ lymphocytes, plasma cells, and neutrophils. ${ }^{36-38}$ Another critical element in the inflamed synovium is the dysregulation of normal 
apoptosis. ${ }^{39}{ }^{40}$ More understanding of the relative contributions of these many factors to the pathogenesis and resolution of arthritis will be elucidated by relating them to the clinical course and outcome, and by evaluating their susceptibility to therapeutic modulation.

\section{Recent application of synovial biopsy to arthritis research}

Some of the early literature emphasised the heterogeneity of histological change in synovial tissue. ${ }^{21-46}$ This caused concern about interpretation of the histopathological features in small samples obtained blindly from only one location. It was suggested that quantitative analysis of synovial tissue might be unreliable owing to unavoidable sampling error. In addition, some of the earlier studies produced conflicting results when correlations between the synovial membrane appearance and the clinical manifestations of RA, including joint damage, were evaluated. These issues were examined extensively in a series of studies which, when taken together, showed that despite the degree of histological variation, representative measures of synovial tissue inflammation may be obtained by examining a limited area of tissue. ${ }^{47-49}$ Some measures of synovial tissue inflammation have been consistently correlated with variables of local or systemic disease activity, severity, and outcome. ${ }^{47}{ }^{50-53}$ In addition, the microscopic characteristics of rheumatoid synovitis are present even in joints that have not yet become overtly inflamed. ${ }^{54-57}$ Finally, in RA the immunohistological features of synovial inflammation change as the clinical manifestations change in response to conventional disease modifying antirheumatic drugs, pulse methylprednisolone, or intra-articular glucocorticoids. ${ }^{50-64}$ These observations from many clinicopathological research protocols have provided compelling evidence to support the inclusion of synovial biopsy and tissue analysis in studies of the cause, pathogenesis, prognosis, and effects of treatment. ${ }^{65}$

Thus, by the early 1990s, several independent and disparate research streams had converged. At the same time, new approaches to treatment, including monoclonal antibody treatment and cytokine blockade, which targeted specific pathogenetic factors in the synovium, were being evaluated in clinical trials.

\section{European Synovitis Study Group}

This convergence stimulated several groups of European investigators to convene at the EULAR meeting in Amsterdam in June 1995. The concerns that were foremost at the time included: ( $a$ ) the need to establish acceptable guidelines for training European rheumatologists in arthroscopic techniques and $(b)$ to consider collaboration in resolving issues related to tissue selection and preparation, and the methods used to quantify the immunohistochemical features of synovial inflammation. The process developed informally with biannual meetings, and a useful forum has evolved for discussing research protocols and data that incorporated synovial biopsy and tissue analysis. The group is now represented on the EULAR Investigative Rheumatology Committee. In addition, the original European focus has been widened by regular collaboration with like-minded investigators from North America and Australia.

GUIDELINES FOR TRAINING IN ARTHROSCOPY

The need to establish acceptable guidelines for training rheumatologists in arthroscopic techniques has been a priority for the group. After considerable discussion, this task has been completed and a document submitted to ILAR for approval and distribution (Reece R, personal communication). The document, which will be published, identifies minimum requirements for the accreditation of trainers and training centres, and outlines a basic curriculum for acquiring the necessary skills in arthroscopy. In addition, procedures for the assessment and accreditation of trainees are proposed.

TISSUE SELECTION

An important practical question was whether arthroscopic synovial biopsy samples, selected under direct vision, were better than needle biopsy specimens in clinicopathological studies. To answer this question the immunohistological features of synovial tissue samples selected at arthroscopy were compared with samples obtained at the same time by needle biopsy from the suprapatellar pouch of the same joint. ${ }^{66}$ The results showed that measurement of most microscopic features of inflammation were similar whether samples were selected under direct vision or obtained blindly by needle biopsy. Moreover, the macroscopic features of inflammation visualised at arthroscopy did not predict the microscopic features. Thus the practical advantages of the closed needle biopsy technique justify its use in many clinicopathological studies. When tissue from specific sites is required or when sample size is important, as in studies which include in vitro experiments, cell separation or analysis of gene expression and protein production, arthroscopic biopsy is a better tissue source.

QUANTIFICATION OF INFLAMMATION IN SYNOVIAL TISSUE SAMPLES

Quantifying the microscopic features of inflammation can be tedious and time consuming. Semiquantitative methods would have the advantages of speed and cost. When semiquantitative and quantitative methods were compared, a cross sectional analysis showed close correlations between the two. ${ }^{67}$ However, in some patients with a clinical response to treatment, the semiquantitative method lacked the sensitivity to recognise some biologically relevant changes which were identified by the quantitative method. Therefore, in studies that seek alterations in the immunohistochemical appearance of synovial membrane-for example, during clinical trials, semiquantitative methods may underestimate the degree of change. 
Computerised digital image analysis has been applied to aspects of histopathological quantification. It offers possibilities of greater objectivity, reliability, and rapidity than other methods. In an initial study, digital image analysis was successfully applied to the measurement of some features of synovial tissue inflammation, including lining layer thickness and $\mathrm{T}$ cell infiltration. ${ }^{68}$ These conclusions were independently confirmed and extended in a separate study, which showed strongly positive correlations between measurements of $\mathrm{T}$ cell and macrophage infiltration obtained by digital image analysis and two other methods. ${ }^{69}$ The results of these two studies support the further development and wider application of digital image analysis in quantifying critical pathological events in the synovium, such as adhesion molecule expression, cytokine and protease production, angiogenesis, and apoptosis.

CLINICOPATHOLOGICAL STUDIES

Pathophysiological studies have been a predominant interest, both within individual groups and in collaborative efforts. Thus studies incorporating synovial biopsy which have emanated from the participating groups and their collaborators have analysed several pathophysiological mechanisms. There has been particular emphasis on studying the pathophysiological events in the synovium of patients with early arthritis, when cell adhesion molecules are upregulated ${ }^{70}$ and mononuclear cells, including $\mathrm{T}$ and $\mathrm{B}$ lymphocytes and macrophages, are diffusely present. ${ }^{53} 56$ Proinflammatory cytokines, tissue degrading enzymes, and other mediators of synovial inflammation and matrix degradation are also expressed in abundance in very early arthritis. ${ }^{71-75}$ Studies have also examined mechanisms of cell interaction, activation, and apoptosis. ${ }^{76-78}$ The observations highlight the need to consider very early introduction of effective treatment that will reduce the tissue damaging effects of persistent synovial pathophysiological activity in several categories of chronic arthritis, particularly in RA. ${ }^{79}$

\section{EVALUATION OF TREATMENT}

Another major interest of the group has been the evaluation of pathophysiological changes in synovial tissue obtained from patients receiving new targeted treatment. In some multicentre studies, biopsy samples taken before and after treatment were pooled or exchanged to maximise the numbers studied or to validate results between centres. These studies have facilitated the evaluation of modes of action and the efficacy of several putative therapeutic advances, including treatment with monoclonal anti-T cell antibodies, ${ }^{80}{ }^{81}$ inhibition of the proinflammatory cytokines, tumour necrosis factor $\alpha^{82} 83$ and interleukin $1 \beta,{ }^{84}$ and the anti-inflammatory cytokine, interferon $\beta .^{85}$ Initial studies suggest that targeted treatments produce profound effects on cellular infiltration on the synovium, ${ }^{80-84}$ associated with inhibition of adhesion molecule expression ${ }^{82} 84$ and reduced production of cytokines and chemokines. ${ }^{83}$
Treatment with interferon $\beta$ was also associated with reduced cellular infiltration and collagenase production. ${ }^{85}$

\section{WORK IN PROGRESS}

Collaborative protocols that are currently approaching completion are part of the standardisation process for quantifying the features of synovial inflammation, both macroscopically at arthroscopy and microscopically by immunohistochemistry. These protocols involve several centres exchanging video images of inflamed synovium acquired at arthroscopy, and tissue sections for microscopic analysis by conventional methods and, in some centres, by digitalised image analysis. These studies are critical to ensure that optimal technological standards are maintained and to minimise interobserver variation between centres.

\section{Conclusion}

Synovial biopsy is now widely practised in arthritis research. Multiple tissue samples can be readily obtained using closed needle biopsy, usually from the suprapatellar pouch. This source may be suitable for many clinicopathological studies. Needle arthroscopy is considerably more expensive, but provides larger samples which can be selected under direct vision. The European Synovitis Study Group was convened five years ago as a forum for discussing, planning, and evaluating studies that may involve arthroscopy, synovial biopsy, or tissue analysis. The group now reports officially to EULAR. The current priorities of the group include studying the pre-erosive phase of destructive arthritis, and evaluating the effects of new treatments on the pathogenetic pathways associated with inflammation and matrix degradation.

1 Garrod $\mathrm{AB}$. The nature and treatment of gout and rheumatic gout. London: Walton and Maberly, 1859 .

gout. London: Walton and Maberly, 1859 .
2 Kulka JP. The pathogenesis of rheumatoid arthritis. Journal of Chronic Diseases 1959;10:388-402.

3 Forestier J. Instrumentation pour biopsie medicale. Comptes Rendus des Seances-Société de Biologie et de ses Filiales 1932;110:186-7.

4 Polley HF, Bickle WH, Dockerty MB. Experiences with an instrument for punch biopsy of synovial membrane. Mayo Clin Proc 1951;26:273-81.

5 Zeveley HA, French AJ, Mikkelsen WM, Duff IF. Synovial specimens obtained by knee joint punch biopsy. Histologic study in joint diseases. Am J Med 1956;20:510-19.

6 Parker HR, Pearson CM. A simplified synovial biopsy needle. Arthritis Rheum 1963;6:172-6.

7 Kinsella TD, Baum J, Ziff M. Studies of isolated synovial Kinsella TD, Baum J, Ziff M. Studies of isolated synovial
lining cells in rheumatoid and non-rheumatoid synovial membranes. Arthritis Rheum 1970;13:734-53.

8 Schumacher HR, Kitridou RC. Synovitis of recent onset. A clinicopathologic study during the first month of disease. Arthritis Rheum 1972;15:465-85.

9 O'Rourke KS, Ike RW. Diagnostic arthroscopy in the arthritis patient. Rheum Dis Clin North Am 1994;20:321-42.

10 Arnold WJ. Office-based arthroscopy. Bull Rheum Dis 1992;41:3-6.

11 Chang RW, Sharma L. Why a rheumatologist should be interested in arthroscopy. Arthritis Rheum 1994;37: 1573-6.

12 Reece RJ, Emery P. Needle arthroscopy. Br J Rheumatol 1995;34:1102-4.

13 Ayral X, Dougados M, Listrat V, Bonvarlet J-P, Simmonet J, Amor B. Arthroscopic evaluation of chondropathy. J Rheumatol 1996;23:698-706.

14 Kobayashi I, Ziff M. Electron microscopic studies of the cartilage-pannus junction in rheumatoid arthritis. Arthritis cartilage-pannus junction in

15 Fassbender HG. Histomorphologic basis of articular cartilage destruction in rheumatoid arthritis. Collagen and Related Research 1983;3:141-55. 
16 Shiozawa S, Shiozawa K, Fujita T. Morphologic observations in the early phase of the cartilage-pannus junction: light and electron microscopic studies of active cellular pannus. Arthritis Rheum 1983;26:472-8.

17 Iguchi T, Kurosaka M, Ziff M. Electron microscopic study of HLA-DR and monocyte/macrophage staining cells in the rheumatoid synovial membrane. Arthritis Rheum 1986;29:600-13.

18 Evanson JM, Jeffrey JJ, Krane SM. Human collagenase: identification and characterization of an enzyme from rheumatoid synovium in culture. Science 1967;158:499502 .

19 Woolley DE, Crossley MJ, Evanson JM. Collagenase at sites of cartilage erosion in the rheumatoid joint. Arthritis of cartilage erosion in

20 Klareskog L, Forsum U, Kabelitz D, Ploen L, Sundstrum C, Nillson $\mathrm{K}$, et al. Immune functions of human synovial cells. Phenotypic and $T$ cell regulatory properties of macrophage-like cells that express HLA-DR. Arthritis Rheum 1982;25:488-501.

21 Dayer J-M, Beutler B, Cerami A. Cachectin/tumor necrosis factor stimulates collagenase and prostaglandin E2 production by human synovial cells and dermal fibroblasts. J Exp Med 1985;162:2163-8.

22 Burmester GR, Jahn B, Rowher P, Zacher J, Winchester RJ, Kalden JR. Differential expression of Ia antigens by rheumatoid synovial cells. J Clin Invest 1987;80:595-604.

23 Firestein GS, Alvaro-Gracia JM, Maki R. Quantitative analysis of cytokine gene expression in rheumatoid analysis of cytokine gene expression
arthritis. J Immunol 1990;144:3347-53.

24 Koch AE, Kunkel SL, Burrows JC, Evanoff HL, Haines GK, Pope RM, et al. Synovial tissue macrophage as a source of the chemotactic cytokine IL-8. J Immunol 1991; 147:2187-95

25 Chu CQ, Field M, Feldmann M, Maini RN. Localisation of tumor necrosis factor $\alpha$ in synovial tissues at the cartilagepannus junction in rheumatoid arthritis. Arthritis Rheum 1991;34:1125-32.

26 Gravallese EM, Darling JM, Ladd AL, Katz JN, Glimcher LH. In situ hybridization studies of stromelysin and collagenase messenger RNA expression in rheumatoid synovium. Arthritis Rheum 1991;34:1076-84.

27 Trabandt A, Aicher WK, Gay RE, Sukhatme VP, Fassbender H-G, Gay S. Spontaneous expression of immediate-early response genes c-fos and egr-1 in collagenase-producing rheumatoid synovial fibroblasts. Rheumatol Int 1992;12:53-9.

28 Wilkinson LS, Pitsillides AA, Worrall JG, Edwards JCW. Light microscopic characterization of the fibroblast-like synovial intimal cell (synoviocyte). Arthritis Rheum 1992;35:1179-84.

29 Allard SJ, Bayliss MT, Maini RN. The synovium-cartilage junction in the normal knee: implications for joint destruction and repair. Arthritis Rheum 1990;33:1170-9.

30 Firestein GS. Invasive fibroblast-like synoviocytes in rheumatoid arthritis: passive responders or transformed aggressors? Arthritis Rheum 1996:39:1781-90.

31 Burmester GR, Stuhmuller B, Keyszer G, Kinne RW. Mononuclear phagocytes and rheumatoid synovitis: mastermind or workhorse in arthritis? Arthritis Rheum 1997;40:5-18.

32 Tetlow LC, Woolley DE. Mast cells, cytokines, and metalloproteinases at the rheumatoid lesion: dual immunolocalisation studies. Ann Rheum Dis 1995; 54:896-903.

33 Zvaifler NJ, Tsai V, Alsalameh S, von Kempis J, Firestein GS, Lotz M. Pannocytes: distinctive cells found in rheuma-
toid arthritis articular erosions. Am J Pathol 1997;150: toid arth 1125 -38.

34 Gravallese EN, Harada Y, Wang J-T, Gorn JH, Thornhill TS, Goldring SR. Identification of cell types responsible for bone resorbtion in rheumatoid arthritis and juvenile rheumatoid arthritis. Am J Pathol 1998;152:943-51.

35 Koch AE. Angiogenesis: implications for rheumatoid arthritis. Arthritis Rheum 1998;41:951-62.

36 Ishikawa $H$, Ziff $M$. Immunoreactive cells in the rheumatoid synovial membrane. Arthritis Rheum 1976;19:1-14.

37 Janossy G, Panayi G, Duke O, Bofill M, Poulter LW, Goldstein G. Rheumatoid arthritis: a disease of T lymphocyte/ macrophage immunoregulation. Lancet 1981;ii:839-42.

38 Thomas R, Lipsky PE. Presentation of self-peptides by dendritic cells: possible implications for the pathogenesis of rheumatoid arthritis. Arthritis Rheum 1996;39:183-90.

39 Firestein GS, Yeo M, Zvaifler NJ. Apoptosis in rheumatoid arthritis synovium. J Clin Invest 1995;96:1631-8.

40 Nakajima T, Aono H, Hasunuma T, Yamamoto K, Shirai T, Hirohata $\mathrm{K}$, et al. Apoptosis and functional Fas antigen in Hirohata K, et al. Apoptosis and functional Fas antigen in rheumatoid

41 Cruikshank B. Interpretation of multiple biopsies of synovial tissue in rheumatic diseases. Ann Rheum Dis 1952;11: 137-45.

42 Jayson MIV, Dixon AStJ. Arthroscopy of the knee in rheumatoid diseases. Ann Rheum Dis 1968;27:503-11.

43 Yates DB, Scott JT. Rheumatoid synovitis and joint disease: relationship between arthroscopic and histologic changes. Ann Rheum Dis 1975;34:1-6.

44 Henderson DRF, Jayson MIV, Tribe CR. Lack of correlation of synovial histology with joint damage in rheumatoid arthritis. Ann Rheum Dis 1975;34:7-11.

45 Lindblad S, Hedfors E. Intra-articular variation in synovitis. Local macroscopic and microscopic signs of inflammatory
activity are significantly correlated. Arthritis Rheum 1985; 28:977-86.
46 Hutton CW, Hinton C, Dieppe P. Intra-articular variation of synovial changes in knee arthritis: biopsy study comparing changes in patellofemoral synovium and the media tibiofemoral synovium. Br J Rheumatol 1987;26:5-8

47 Rooney M, Condell D, Quinlan W, Daly L, Whelan A, Feighery C, et al. Analysis of the histologic variation of synovitis in rheumatoid arthritis. Arthritis Rheum 1988;31: 956-63.

48 Bresnihan B, Cunnane G, Youssef P, Yanni G, FitzGerald O, Mulherin D. Microscopic measurement of synovial membrane inflammation in rheumatoid arthritis: proposals for the evaluation of tissue samples by quantitative analysis. $\mathrm{Br}$ J Rheumatol 1998;37:636-42.

49 Dolhain RJEM, ter Haar NT, de Kuiper R, Nieuwenhuis IG, Zwinderman AH, Breedveld FC, et al. Distribution of $T$ cells and signs of $T$ cell activation in the rheumatoid joint: implications for semiquantitative comparative histology. Br J Rheumatol 1998;37:324-30.

50 Rooney M, Whelan A, Feighery C, Bresnihan B. Changes in lymphocyte infiltration of the synovial membrane and the clinical course of rheumatoid arthritis. Arthritis Rheum 1989;32:361-9.

51 Rooney M, Whelan A, Feighery C, Bresnihan B. The immunohistologic features of synovitis, disease activity and in-vitro IgM rheumatoid factor synthesis by blood mononuclear cells in rheumatoid arthritis. J Rheumatol 1989;16:459-67.

52 Mulherin D, FitzGerald O, Bresnihan B. Synovial tissue macrophage populations and articular damage in rheumatoid arthritis. Arthritis Rheum 1996;39:115-24.

53 Tak PP, Smeets TJM, Daha MR, Kluin PM, Meijers KAE, Brand R, et al. Analysis of the synovial cellular infiltrate in early rheumatoid synovial tissue in relation to local disease activity. Arthritis Rheum 1997;40:217-25.

54 Soden M, Rooney M, Cullen A, Whelan A, Feighery C, Bresnihan B. Immunohistologic features in the synovium from clinically uninvolved knee joints of patients with rheumatoid arthritis. Br J Rheumatol 1989;28:287-92.

55 FitzGerald O, Soden M, Yanni G, Robinson R, Bresnihan B. Morphometric analysis of blood vessels in synovial membranes obtained from clinically affected and unaffected knee joints of patients with

56 Kraan MC, Versendaal H, Jonker M, Bresnihan B, Post W, t'Hart BA, et al. Asymptomatic synovitis precedes clinically manifest arthritis. Arthritis Rheum 1998;41:1481-8.

57 Pando JA, Duray P, Yarboro C, Gourley MF, Klippel JH, Schumacher HR. Synovitis occurs in some clinically normal and asymptomatic joints in patients with early arthritis. J Rheumatol (in press)

58 Walters MT, Smith JL, Moore K, Evans PR, Cawley MID. An investigation of the action of disease modifying anti-rheumatic drugs on the rheumatoid synovial membrane: reduction in $\mathrm{T}$ lymphocyte subpopulations and HLA-DP and DQ antigen expression after gold or penicillamine therapy. Ann Rheum Dis 1987;30:1-10.

59 Firestein GS, Paine MM, Littman BH. Gene expression (collagenase, tissue inhibitor of metalloproteinases, complement and HLA-DR) in rheumatoid arthritis synovium. Quantitative analysis and effect of intra-articular corticosteroids. Arthritis Rheum 1991;34:1094-105.

60 Firestein GS, Paine MM, Boyle DL. Mechanism of methotrexate action in rheumatoid arthritis. Selective decrease in synovial collagenase gene expression. Arthritis Rheum 1994;37:193-200.

61 Yanni G, Farahat MNMR, Poston RN, Panayi GS Intramuscular gold decreases cytokine expression and macrophage numbers in the rheumatoid synovial membrane. Ann Rheum Dis 1994;53:315-22.

62 Youssef PP, Cormack J, Evill CA, Peter DT, RobertsThompson PJ, Ahern MJ, et al. Neutrophil trafficking into inflamed joints in patients with rheumatoid arthritis and the effect of methylprednisolone. Arthritis Rheum 1996; 39:236-42.

63 Youssef PP, Haynes DR, Triantafillou S, Parker A, Gamble JR, Roberts-Thomson PJ, et al. Effects of pulse methylprednisolone on inflammatory mediators in peripheral blood, synovial fluid, and synovial membrane in rheumatoid arthritis. Arthritis Rheum 1997;40:1400-8.

64 Dolhain RJEM, Tak PP, Dijkmans BAC, de Kuiper P, Breedveld FC, Miltenburg AMM. Methotrexate treatment reduced inflammatory cell numbers, expression of monokines and of adhesion molecules in synovial tissue of patients with rheumatoid arthritis. $\mathrm{Br} \mathrm{J}$ Rheumatol 1998;37:502-8

65 Bresnihan B, Tak PP. Synovial tissue analysis in rheumatoid arthritis. Ballieres Clin Rheumatol 1999;13:645-59.

66 Youssef PP, Kraan M, Breedveld F, Bresnihan B, Cassidy N, Cunnane G, et al. Quantitative analysis of inflammation in rheumatoid arthritis synovial membrane samples selected at arthroscopy compared with samples obtained blindly by needle biopsy. Arthritis Rheum 1998;41:663-9.

67 Youssef PP, Smeets TJM, Bresnihan B, Cunnane G, FitzGerald O, Breedveld F, et al. Microscopic measurement of cellular infiltration in the rheumatoid arthritis synovial membrane: a comparison of semiquantitative and
tive analysis. $\mathrm{Br}$ J Rheumatol 1998:37:1003-7.

68 Cunnane G, Bjork L, Ulfgren A-K, Lindblad S, FitzGerald $\mathrm{O}$, Bresnihan $\mathrm{B}$, et al. Quantitative analysis of synovial membrane inflammation: a comparison between automated and conventional microscopic measurements. Ann Rheum Dis 1999;58:493-9. 
69 Kraan MC, Haringman JJ, Ahern MJ, Breedveld FC, Smith MD, Tak PP. Quantification of the cell infiltrate in synovial
tissue by digital image analysis. Rheumatology 2000;39: tissue

70 Tak PP, Thurkow EW, Daha MR, Kluin PM, Smeets TJM, Meinders AE, et al. Expression of adhesion molecules in early rheumatoid synovial tissue. Clin Immunol Immunopathol 1995;77:236-42.

71 Smeets TJM, Dolhain RJEM, Breedveld FC, Tak PP. Analysis of the cellular infiltrates and expression of cytokines in synovial tissue from patients with rheumatoid arthritis. J Pathol 1998;186:75-81.

72 Smeets TJM, Dolhain RJEM, Miltenburg AMM, de Kuiper R, Breedveld FC, Tak PP. Poor expression of T cell-derived cytokines and activation and proliferation markers in early rheumatoid synovial tissue. Clin Immunol Immunopathol 1998;88:84-90.

73 Cunnane G, FitzGerald O, Hummel KM, Gay RE, Gay S, Bresnihan B. Collagenase, cathepsin B and cathepsin I gene expression in the synovial membrane of patients with gene expression in the synovial membrane of patients

74 Ulfgren A-K, Grondal L, Lindblad S, Johnell O, Klareskog L, Andersson U. Patterns of cytokine production vary considerably among patients with rheumatoid arthritis. Ann Rheum Dis (in press)

75 O'Hara R, Murphy EP, Whitehead AS, FitzGerald O, Bresnihan B. Acute phase serum amyloid A production by rheumatoid arthritis synovial tissue. Arthritis Research 2000;2:142-4.

76 Tak PP, Kummer A, Hack CE, Daha MR, Smeets TJM, Erkelens GW, et al. Granzyme-positive cytotoxic cells are specifically increased in early rheumatoid synovial tissue. Arthritis Rheum 1994;37:1735-43.

77 Hamann J, Wishaupt JO, van Lier RAW, Smeets TJM, Breedveld FC, Tak PP. Expression of the activation antigen CD97 and its ligand CD55 in rheumatoid synovial tissue. Arthritis Rheum 1999;42:650-8.
78 Tak PP, Smeets TJM, Boyle DL, Kraan MC, Shi Y, Zhuang $\mathrm{S}$, et al. p53 overexpression in synovial tissue from patients with early and longstanding rheumatoid arthritis compared with reactive arthritis and osteoarthritis. Arthritis Rheum 1999;42:948-53.

79 Emery P. The optimal management of early rheumatoid disease: the key to preventing disability. Br J Rheumatol 1994;33:765-8.

80 Tak PP, van der Lubbe PA, Cauli A, Daha MR, Smeets TJM, Kluin PM, et al. Reduction of synovial inflammation after monoclonal anti-CD4 monoclonal antibody treatment in early rheumatoid arthritis. Arthritis Rheum 1995; 38:1457-65.

81 Veale DJ, Reece RJ, Parsons W, Radjenovic A, O'Connor PJ, Orgles CS, et al. Intra-articular primatised anti-CD4: efficacy in resistant rheumatoid knees. A study of combined arthroscopy, magnetic resonance imaging, and histology. arthroscopy, magnetic resonance

82 Tak PP, Taylor PC, Breedveld FC, Smeets TJM, Daha MR, Kluin PM, et al. Decrease in cellularity and expression of adhesion molecules by anti-tumor necrosis factor $\alpha$ monoclonal antibody treatment in patients with rheumatoid clonal antibody treatment in patients with

83 Taylor PC, Peters AM, Paleolog E: Chapman PT, Elliott MJ, McCloskey R, et al. Reduction of chemokine levels and eukocyte traffic to joints by tumor necrosis factor $\alpha$ blockade in patients with rheumatoid arthritis. Arthritis Rheum $2000 ; 43: 38-47$

84 Cunnane G, Madigan A, Murphy E, FitzGerald O, Bresnihan B. The effects of treatment with interleukin-1 receptor antagonist on the inflamed synovial membrane in rheumatoid arthritis. Rheumatology (in press).

85 Smeets TJM, Dayer J-M, Kraan MC, Versendaal J, Chicheportiche R, Breedveld FC, et al. The effects of interferon $\beta$ treatment on synovial inflammation and expression of metalloproteinases in patients with rheumatoid arthritis. Arthritis Rheum 2000;43:270-4. 